\title{
LORD IRONSIDE AND SIR WINSTON CHURCHILL'S ESCAPE FROM CAPTIVITY DURING THE BOER WAR
}

\author{
Colonel E. J. S. BONNETT, M.R.C.S., L.R.C.P., D.P.H., Late R.A.M.C.
}

I FIRST met Field Marshal Lord Ironside in 1921. As General-Officer-Commanding (G.O.C.) Middle East Command he had been involved in an aircraft accident in Mesopotamia whilst being flown back from Egypt, where he had been in conference in Cairo with Mr. Winston Churchill, Colonial Secretary in the Lloyd George Government. His aircraft - a 2 seater biplane, on landing in a sand storm ran into a nullah (ditch). The General, sitting in the rear gunner's seat, perched up owing to his size, was pitched out and sustained a fractured femur. He was admitted to No. 3 British General Hospital (B.G.H.), Basrah, under the care of Major Dan McVickar R.A.M.C. (Surgical Specialist). There his condition began to cause anxiety with the advent of the very hot weather, and as he had been suffering also from sandfly fever, it was decided to invalid him home to the United Kingdom (U.K.).

I had, at that time, reported to the British Base Depot, Magil, Basrah Camp awaiting embarkation to Home Establishment after completing my tour of active service in Mesopotamia. From here I was detailed by the Assistant Director of Medical Services, Basrah to report to No. 3 B.G.H. and take over the care and treatment of General Ironside, and to supervise his embarkation in the Royal Indian Marine Ship ". Hardinge " on Thursday, 26th May 1921. I was also Officer in Medical charge of troops on board (19th Brigade, Royal Artillery and Details) - a full time job. There were no Nursing Sisters.

The General, owing to his size (six foot six inches tall) and being on a Thomas Splint, could not be accommodated in the Ship's Sick Bay, or an ordinary cabin. He was, therefore, warded in the private Sitting Room (Cabin) of the Captain of the " Hardinge".

Our departure was not without incident. We sailed from Basrah at noon on Thursday, 26th May 1921, but the ship ran aground on the shallows (the Bar) at the mouth of the Shatt-al-Arab; First attempts to free the ship failed, and it was not until troops and baggage had been taken off in life boats and lighters, and the Ship's Engineers had pumped out the water tanks that the ship was afloat again. Very hot work in the Persian Gulf, and $I$ had a few cases of Heat Exhaustion. Having then to return to Basrah for fuel and water, we left again on Saturday, 5th June 1921, and this time all was plain sailing.

During the voyage, in the evenings, the Ship's Captain, Officer Commanding Troops, Chief Officer, and Chief Engineer, and myself used to foregather at the Generals bedside for our "Sundowner" and discourse. I was relatively junior at the time and felt privileged to be in at these interesting talks. I recollect how surprised I was when our impressive G.O.C. said that he had not been able to convince Winston Churchill regarding his (Ironsides) policy for the defence of the Middle East. I felt that Churchill (then in his forties) must be a dour and tough debator.

Another story "Tiny" Ironside told me was how before the 1914 War he had served in a regiment of the Prussian Guard, and had been promoted to Corporal. Quite a story on its own! 
In 1959 Lord Ironside again fractured a femur in an accident in his Norfolk Home and became a patient in The Queen Alexandra Military Hospital, Millbank, London. Here I visited him on the 9th September 1959.

My diary of 1959 records that I reminded the Field Marshal of the events of his invaliding home from Mesopotamia in 1921, when in his cabin in the "Hardinge" he had told us of his confrontation with Mr. Winston Churchill at the Cairo Conference 1921.

Lord Ironside then told me this story-one other person was present-a middle aged man whose name $I$ cannot remember not having entered it in my diary.

"I knew Winston Churchill very well, as, in the early days of the Boer War I was out there serving with a Special Force and working largely on my own as I spoke German and Afrikaans fluently, and by this means I helped to increase my pay being a somewhat impecunious Gunner Subaltern. I took on a Basuto Servant, and soon learn this language. In my roving job I developed scouting techniques and got to know of the movements and strengths of the Boer Commandoes. This information I passed on to the British Staff, and, I believe, it impressed General Baden Powell of the value of Scouting; and this no doübt led him to the founding of the Boy Scout Movement after the Boer War.

At about the turn of the century Lieutenant Winston Churchill came out to South Africa and to the War Zone as a correspondent and reporting for the London " Morning Post ", and not as a Hussar Officer.

Churchill heard about my experience of the country and Boers. We met, got to know each other well, both of us being young ambitious regular officers. He told me he wanted to get up to the Boer Commando at Pretoria in order to get a good story for his newspaper, and if possible, contact his friend Captain Haldane, Sussex Regiment, relative or Lord Haldane, the War Minister, Captain Haldane was a prisoner of war (P.O.W.) in Pretoria. I told Winston it would be foolhardy if he went on the armoured train, as it was likely to be ambushed and derailed, and that he would very likely be shot or become a P.O.W. himself. Churchill however was stubborn, and said he was damn well going to have a try and added, if I should get captured then, Tiny, you as an up and coming adventurous young officer, can come up and get me "out of the bag"!

Well-Churchill went in the armoured train, was ambushed, and was captured by the Boers and put in the P.O.W. Prison in Pretoria.

I felt I ought to do something about it, so I raised some funds from the British Community in Cape Tówn, bought a Vortreck Waggon and team of oxen, and with my Basuto boy trekked up to Pretoria disguised as a Boer. I hadn't any definite plan of action, but I had a stroke of luck when, at a Prayer Meeting, or some such function, I met and got to know a young Boer woman. After I had got to know her well, I confessed I was not a Boer but a British Officer, that I was not spying, but was on a delicate mission; this was to try and get the release of a certain young man of an aristocratic British family who had been captured. This was Winston Spencer Churchill of the Marlborough family. He, Winston, I explained, was a journalist out to get war news and a story for the World, and he was not spying or fighting the Boers. I now had to think up a fictitious story in order to impress her, and this was, that young Churchill was engaged to a lady-daughter of an English aristocrat and was due soon to be married. It was essential this marriage should take place, as the young woman, due to 


\section{$1 \mathrm{mg}$.}

Tablets $1 \mathrm{mg}$. permit easy adjustment of dosage when initiating treatment
$2 \mathrm{mg}$.

'Spansule' Capsules 2mg. provide an exceptionally convenient dosage unit for routine use
Syrup $1 \mathrm{mg} . / 5 \mathrm{ml}$.

A palatable Syrup to meet the need for liquid therapy whenever this is preferred by either doctor or patient
Ampoules $1 \mathrm{mg} . / 1 \mathrm{ml}$. For rapid effect in the extremely agitated or disturbed psychoneurotic patient

\section{anxiety states respond swiftly to the true tranquillizing effect of}

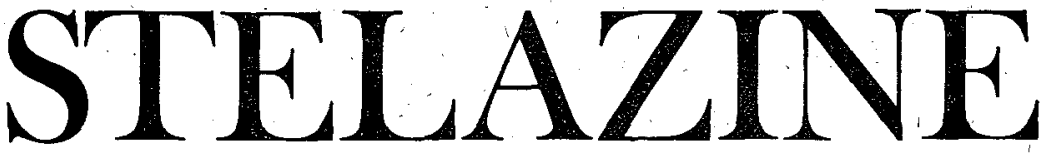

Literature giving full prescribing information is available on request.

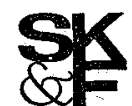




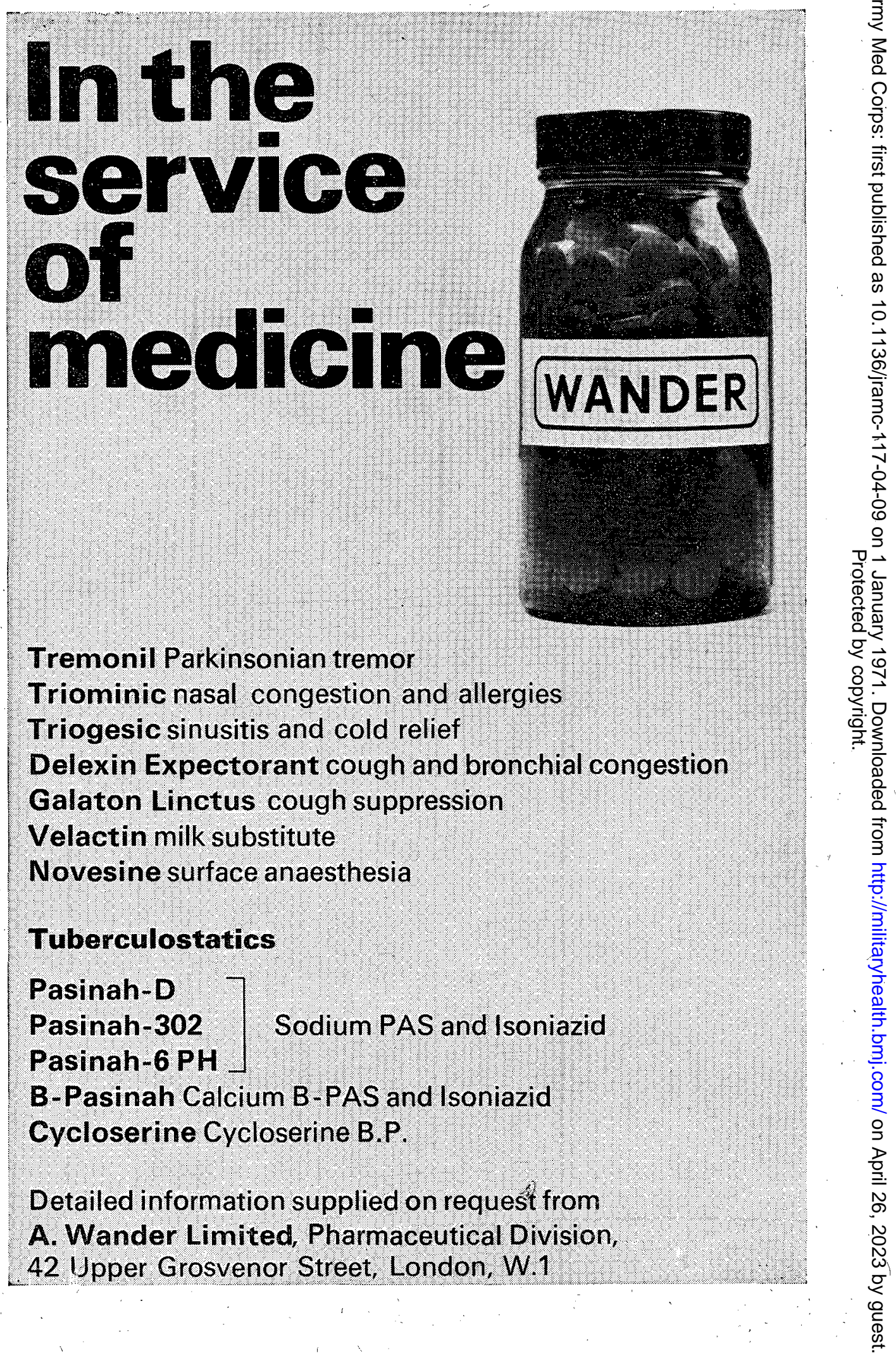


indiscretion, was pregnant, and had come out to Cape Town for the wedding. Failure to get married could bring disgrace to the young woman and to two noble families. I appealed to her to help another woman in distress.

I was successful in arousing her sympathy, and through her I got a message in to Winston Churchill; the jailer was " hoodwinked" and Churchill's escape made possible. We get him away, and so to the railway where Churchill stowed himself away amongst the bales of fodder and other goods.

The story of this adventurous rail-journey is told by Churchill in his book " My Early Life".

I was enthralled by this story as told by Lord Ironside, but felt I could not quiz or ask him more questions about it that afternoon. I hoped that I might later have an opportunity to do so.

A few days later I sailed in the s.s. "Empress of Britain" for Canada. Whilst steaming up the St. Lawrence River, and just before reaching Montreal on Friday 25 th September 1959, a Wireless Newsflash was received and printed on the Ship's News Sheet. It announced the sudden death of Field Marshal Lord Ironside in a Military Hospital in London, England.

\section{Postgraduate Dean -Edinburgh}

Major-General J. M. Matheson, O.B.E., T.D., Q.H.S., M.D., M.R.C.P., F.R.C.S., has been appointed Postgraduate Dean in the Faculty of Medicine, Edinburgh University, on relinquishing his appointment as Commandant and Director of Studies, Royal Army Medical College and subsequent retirement from the Corps. 